\title{
The Role of Rangelands in Diversified Farming Systems: Innovations, Obstacles, and Opportunities in the USA
}

\author{
Nathan F. Sayre $^{1}$, Liz Carlisle ${ }^{1}$, Lynn Huntsinger $^{2}$, Gareth Fisher $^{2}$ and Annie Shattuck ${ }^{1}$
}

\begin{abstract}
Discussions of diversified farming systems (DFS) rarely mention rangelands: the grasslands, shrublands, and savannas that make up roughly one-third of Earth's ice-free terrestrial area, including some 312 million ha of the United States. Although ranching has been criticized by environmentalists for decades, it is probably the most ecologically sustainable segment of the U.S. meat industry, and it exemplifies many of the defining characteristics of DFS: it relies on the functional diversity of natural ecological processes of plant and animal (re)production at multiple scales, based on ecosystem services generated and regenerated on site rather than imported, often nonrenewable, inputs. Rangelands also provide other ecosystem services, including watershed, wildlife habitat, recreation, and tourism. Even where non-native or invasive plants have encroached on or replaced native species, rangelands retain unusually high levels of plant diversity compared with croplands or plantation forests. Innovations in management, marketing, incentives, and easement programs that augment ranch income, creative land tenure arrangements, and collaborations among ranchers all support diversification. Some obstacles include rapid landownership turnover, lack of accessible U.S. Department of Agriculture certified processing facilities, tenure uncertainty, fragmentation of rangelands, and low and variable income, especially relative to land costs. Taking advantage of rancher knowledge and stewardship, and aligning incentives with production of diverse goods and services, will support the sustainability of ranching and its associated public benefits. The creation of positive feedbacks between economic and ecological diversity should be the ultimate goal.
\end{abstract}

Key Words: diversification, ecosystem services, ranching, rangelands

\section{INTRODUCTION: RANCHING AND DIVERSIFIED FARMING SYSTEMS}

Discussions of diversified farming systems (DFS) rarely mention rangelands, even though they are a significant part of the land base used for agricultural production. The omission may reflect the fact that rangelands are not cultivated, and therefore seem unrelated to farming. To achieve sustainability and high productivity, however, DFS must find ways of connecting crop and livestock production at scales from individual farms to landscapes and regions, and rangelands can and should be a part of this endeavor. Defined here as nonirrigated lands on which the natural vegetation is native grasses, grass-like plants, forbs, shrubs suitable for grazing and browsing, and/or introduced forage species that are naturalized, rangelands total 312 million ha in the U.S. (USFS 2012), of which 200 million ha are grazed by livestock (USDA-NRCS 2007, Nickerson et al. 2011). Along with 51 million ha of grazed woodlands, these lands make up roughly one-fourth of the United States (Lubowski et al. 2006, USDANRCS 2007, Nickerson et al. 2011).

Although ranching has been criticized by environmentalists for decades, it is probably the most ecologically sustainable segment of the U.S. meat industry (Hodgson and Ilius 1996,
Oltjen and Beckett 1996, Tilman et al. 2002, Hinrichs and Welsh 2003, Gwin 2006), for reasons closely allied to the defining characteristics of DFS: rangeland livestock production relies on natural ecological processes of plant and animal (re)production, based on ecosystem services generated and regenerated on site rather than imported, often nonrenewable, inputs (Kremen et al. 2012). Put more simply, range livestock consume vegetation that grows and reproduces on its own, without anthropogenic irrigation, cultivation, or fertilization. This does not mean that ranching cannot produce ecological damage, e.g., erosion, loss of vegetation, invasive species problems, or impacts to wildlife and wildlife habitat, and it represents only a small part of the U.S. meat production system. However, it highlights the direct dependence of ranching on functional biodiversity at multiple spatial and temporal scales (Kremen et al. 2012, Kremen and Miles 2012), whether or not this diversity is consciously intended. Concurrently, rangelands also provide other ecosystem services, such as watershed, wildlife habitat, recreation, and tourism (Goldstein et al. 2011, Maczko et al. 2011). Even where non-native or invasive plants have encroached on or replaced native species, rangelands retain unusually high levels of plant diversity compared with croplands or plantation

\footnotetext{
${ }^{1}$ Department of Geography University of California-Berkeley, ${ }^{2}$ Department of Environmental Science, Policy, and Management University of CaliforniaBerkeley
} 
forests, and those rangelands that have never been plowed also retain much of their soil and microbial diversity (Havstad and Peters 1999).

However, the economic sustainability of ranching is more precarious than its ecological sustainability. Profit margins are notoriously thin, and one can argue that ranching persists in the U.S. because, and insofar as, more industrial methods of livestock production have thus far been unable to render it economically uncompetitive and obsolete. There are four key elements to this resistance or persistence: (1) Technologies for confined breeding of cattle, sheep, and goats have not yet been developed, in contrast with broiler chickens, turkeys, and hogs. Extensive ranching thus remains economically competitive as a source of young animals, most of which are subsequently fattened in confined feeding operations. (2) On remaining U. S. rangelands, the economic costs of intensive inputs and land manipulations, e.g., irrigation, fertilization, or cultivation, are prohibitively high relative to returns, because of low biological productivity, rugged topography, limited water supplies, etc. (3) There remain large areas of rangelands available for grazing that are not deemed more valuable for other uses, although this is changing because of pressures for energy development, tourism and recreation, and residential (exurban and suburban) land uses (Brown et al. 2005). The market price of ranch land far exceeds what livestock production alone can justify economically (Torell et al. 2005), driving margins still lower. (4) Ranching has long retained and attracted landowners motivated by quality of life or use values, e.g., family or community tradition, attachment to place and nature, as much or more than by financial or exchange values such as profit or return on investment; such owners tolerate unreliable and low, or even negative, returns from livestock production to persist in ranching (Smith and Martin 1972). For example, roughly half of ranchers who lease federal rangelands rely on off-ranch sources for 50\% or more of their income (Gentner and Tanaka 2002), and in some areas so-called "amenity buyers" now dominate ranch real estate transactions (Gosnell et al. 2006). In fact, off-ranch income may represent the most widespread form of diversification in U.S. ranching, albeit one with no simple or necessary relationship to DFS.

This combination of ecological and economic circumstances makes rangelands a valuable source of insights and opportunities for DFS. Compared with the rest of U.S. agriculture, ranching is a tightly coupled social-ecological system. Ranchers must adapt their production to the highly variable conditions of climate and vegetation characteristic of rangelands, and they must do so under economic constraints that preclude resorting to expensive external inputs (Sayre 2001). Because roughly half of U.S. rangelands are publicly owned and governed by multiple use mandates, many ranchers must also manage for a range of public goods and services as well as livestock products.
Across the western U.S., countless examples can be found of individual ranchers, or groups of ranchers, who are finding innovative ways to cope and persist by diversifying their operations. Tables $1-5$ provide a sample of these innovative ranches, categorized by the types of diversification they illustrate: management practices, land tenure arrangements, products, marketing, and services, including ecosystem services that are not yet marketable. We discuss each of these categories of rangeland diversification, exploring the opportunities they represent and the corresponding obstacles to diversified management of rangelands in the U.S. We conclude with policy recommendations to facilitate rangeland DFS.

\section{Diversification through innovative management practices}

The constitutive moment of range livestock production is the animal's act of consuming forage, i.e., herbivory. The sustainability of the operation as a whole depends on the response of plants and plant communities to the selective removal of biomass by the grazing animal, and the persistence of climatic and edaphic factors that support plant growth. The coevolutionary relationship between large grazing animals and the world's rangeland plants, especially grasses, is tens of millions of years old. Domestic livestock production, developed within the last 15 thousand years, augments the grazing of wild animals, insects, and other species. Range livestock managers cannot control the weather. They have only indirect control over herbivory and plant response, but they have an extraordinarily wide spectrum of potential management strategies for doing so, from constant copresence or herding, to the placement of water sources, salt licks, or other supplements to attract livestock to certain areas, to fixed delimitation of grazing areas with fencing. All of these strategies involve trade-offs between costs, for labor, infrastructure, or both, and benefits measured in forage production and effects on the health, growth, and successful reproduction of the livestock being managed.

This rather abstract discussion serves to isolate a key point regarding rangelands and DFS, namely, that range livestock production intrinsically involves interactions of herbivory and plant growth at scales ranging from individual plants to entire landscapes and from days to years. If diversified farming typically denotes multiple crop species grown in combination or in alternating sequences or rotations, in range livestock production a pre-existing and self-perpetuating diversity of plants stays put while the animals move, distributing their impacts spatially and temporally, whether or not the manager is consciously rotating them. Put another way, livestock grazing is an ecological influence that can be managed in terms of timing, frequency, and intensity as well as location (Sayre 2001). 
The recommended management practices of the mid-20th century on U.S. rangelands were oriented toward homogenization of livestock impacts and range landscapes, both spatially and temporally (Fuhlendorf and Engle 2001). Stocking rates were normalized at static levels based on estimates of average annual forage production. Watering points and fences were constructed, and predators controlled, to encourage livestock to be as evenly distributed as possible and thereby to utilize all available forage (Sayre 2002, Sayre and Fernandez-Gimenez 2003). It is now recognized that these strategies were poorly suited to the natural spatial and temporal heterogeneity of many rangelands, and that recommended stocking rates were generally too high, especially in drier years. Management practices today are instead more likely to emphasize flexible stocking, adaptation to local and ephemeral conditions, and grazing systems that manipulate the timing, intensity, and duration of grazing, as well as the type of grazing animal(s), to achieve specific management objectives.

Diversification through management innovation on U.S. rangelands can take many forms but is unified by a few common themes:

1. Reducing operating costs by relying less on purchased inputs and human labor and more on natural processes of plant and animal (re)production. Giving up expensive hay-cutting, storage, and winter feeding in favor of direct livestock herbivory is an example.

2. Restoring or remediating past degradation to improve the underlying productivity of rangelands. Riparian areas are common targets for such efforts.

3. Enhancing the coproduction of ecosystem services such as wildlife habitat, predators, pollinators, or endangered species of plants and animals. There are emerging markets and some payment programs for a variety of rangeland ecosystem services that can augment income from livestock production. As one example, value-added prices may be obtained for livestock produced organically or in environmentally friendly ways.

The management innovations themselves are as diverse as the landscapes, managers, and goals in question. The most widespread grazing systems involve planned movements of herds from one grazing area to another. These rotations may be days or months long, depending on management objectives. The efficacy of rotational grazing in and of itself for increasing production and improving ecological conditions has been debated among range scientists for decades (Briske et al. 2011), and it is not well supported by experimental science (Briske et al. 2008). However, livestock may be moved from one area to another for many different reasons, including avoiding bird nesting areas during the breeding season, concentrating grazing on an invasive species, avoiding drought stricken areas, preventing overuse, or achieving more uniform, or more heterogeneous, consumption of the vegetation. Season-long and year-long grazing remain viable strategies, depending on the management goals (Briske et al. 2011).

Cross-fencing or creating smaller pastures to achieve tighter control on distribution and intensity can enable more flexible and/or targeted grazing for diverse management objectives, although the trade-off is a loss in the apparent "naturalness" of the environment and potential habitat fragmentation for some species. Concentrating livestock in smaller areas, and therefore higher densities, for shorter periods reduces grazing selectivity and is believed to reduce plant competition in more mesic rangelands where competition is not constrained by aridity. For example, Chet Vogt of Three Creeks Ranch in Glenn County, California, rotates his 500 cow/calf pairs among 32 fenced paddocks and a handful of riparian "special management zones," which receive short-duration grazing treatments intended to benefit native plants. Multispecies grazing incorporates multiple kinds of livestock, e.g., goats and/or sheep alongside cattle, to diversify herbivory impacts, i.e., browsing and grazing. Joel Salatin's "Polyface" system is perhaps the best-known example of this type of diversification, but there are numerous others (Table 1). Finally, matching livestock numbers and needs to variable forage conditions involves a kind of temporal diversification and innovation, recognizing that high variability in both production and nutritional content of rangeland vegetation can be tracked by managers and accommodated through flexible stocking, i.e., adjusting herd sizes frequently, and careful timing, e.g., scheduling the herd's peak demand for the time of year when forage quality and quantity are highest. Seedstock producer Kit Pharo and his 28,000-member "herd quitter" newsletter and list-serv focus on this forage balancing act as the cornerstone of sound ranch planning.

\section{Diversification of land access and tenure arrangements}

Sometimes by choice, but more often by necessity, ranchers in the western U.S. manage a diverse combination of land tenure arrangements, frequently relying on both public and private land to support their herds through the year. As a result of historic U.S. land allocation policies, private land owned by western ranchers is seldom enough to maintain an economically viable operation. Further, a key strategy is the use of different elevations and vegetation types depending on the season and weather patterns, but owning enough land to encompass such topographic variation is rare. Instead, nearly 30,000 U.S. ranchers utilize federal grazing leases on more than 94 million ha of rangelands administered by the U.S. Forest Service (USFS) and Bureau of Land Management (BLM; Gentner and Tanaka 2002, GAO 2005). These leases are linked to parcels of private land and typically transfer when the parcels change hands, because the public lands are an indispensable part of the ranch. Many ranchers move their herds between public and private land every year, using 
Table 1. Diversification through innovative management practices.

\begin{tabular}{|c|c|c|}
\hline Diversified Farming Systems Attribute & Case Studies & Web site/Reference \\
\hline \multirow[t]{8}{*}{ Grazing systems } & Holistic Management International & $\begin{array}{l}\text { http://www.holisticmanagement.org/index.php? } \\
\text { option=com content\&view= } \\
\text { article\&id=77\&Itemid }=45\end{array}$ \\
\hline & JX Ranch Natural Beef & http://www.leannaturalbeef.com/about-us.htm \\
\hline & Blue Range Ranch & http://bluerangeranch.com \\
\hline & Three Creeks Ranch & $\begin{array}{l}\text { http://www.sandcounty.net/initiatives/LCA/ } \\
\text { Winners/CA/?ID }=159\end{array}$ \\
\hline & Ray Banister & $\overline{\text { Provenza } 2007}$ \\
\hline & 47 Ranch & Barnes 2011 \\
\hline & Empire Ranch & http://www.empireranchfoundation.org \\
\hline & Nicasio Native Grass Ranch & $\begin{array}{l}\text { http://www.marinorganic.org/producers/ } \\
\text { producers nicasio native.html }\end{array}$ \\
\hline \multirow[t]{10}{*}{ Multispecies grazing } & Tamarack Lamb and Wool & http://tamaracksheep.com/ \\
\hline & Fox Fire Farms & http://www.foxfirefarms.com/ \\
\hline & 47 Ranch & Barnes 2011 \\
\hline & Polyface & http://www.polyfacefarms.com \\
\hline & James Ranch & http://www.jamesranch.net \\
\hline & Ladder Ranch & http://www.ladderranch.com \\
\hline & Hobo Ranch & http://www.hoboranches.com \\
\hline & Marin Sun Farms & http://www.marinsunfarms.com \\
\hline & Parker Pastures & http://parkerlandmanagement.com \\
\hline & Rehoboth Ranch & http://www.rehobothranch.com \\
\hline \multirow{3}{*}{$\begin{array}{l}\text { Matching livestock numbers and needs to variable } \\
\text { forage conditions }\end{array}$} & Pharo Cattle Company & http://pharocattle.com/ \\
\hline & Lasater Ranch & http://www.lasaterranch.com \\
\hline & Ray Banister & Provenza 2007 \\
\hline
\end{tabular}

montane national forest range for summer feed and lower elevation BLM land in winter (Rinschede 1984, Huntsinger et al. 2010a). Private livestock also graze land owned by other public agencies, including the National Park Service, U.S. Fish and Wildlife Service, Bureau of Reclamation, and the Departments of Defense and Energy (GAO 2005); state land departments (Souder and Fairfax 1996); county, regional, or municipal utility and park districts; and public universities. Grazing lands are also owned and managed by a wide variety of private landlords, including individuals, private universities, land conservancies, partnerships, and corporations, notably precious metal mining, oil, or diversified holding companies. One rancher in the Sierra Nevada foothills used 10 to 15 different private and public leases to support his cattle through the year (Sulak and Huntsinger 2007). All of these ownerships may offer profitable leasing opportunities, and could present ranchers with the opportunity to diversify products, services, and management. For example, animal unit months (AUMs), in which federal leases are administered, on BLM allotments can be converted between cattle and sheep.

Ideally, public and private components of a ranch are adjacent, or close enough to move livestock without the use of vehicles, but this is not always the case. In regions where competition for leases is stiff, often because of development pressure, ranchers piece together noncontiguous parcels to make their operations viable (Sulak and Huntsinger 2007). Crucial to diverse land tenure arrangements is a rancher's ability to move livestock within or between these parcels. Hence, rights of way for moving livestock, under their own power or with trucks, are essential. Mobility has been highlighted globally as a central component of extensive livestock grazing systems and is beginning to find a place in the literature on North American working landscapes (Huntsinger et al. 2010a). Public stock driveways remain crucial to some large range sheep and cattle operations, and many western states' open range and right-of-way laws favor livestock over cars on public rural roads (G. S. Fisher, unpublished manuscript). Informal or customary agreements to allow livestock movement across private lands have been documented among long-time neighboring ranchers in Montana (Yung and Belsky 2007). For ranches fragmented and contiguous alike, human assistance in livestock movement is essential. The Ellison Ranching Company, based in Tuscarora, Nevada, moves sheep by their own power over 200 miles on a round trip between summer and winter grazing allotments, and is dependent on trailing permits and long-established stock driveways for these movements.

In the case of private rangelands, the various property rights associated with ownership, often described with the metaphor of a bundle of sticks, represent a significant opportunity for diversification. Conservation easements, in which development rights are sold to a land trust or a government entity, have generated considerable enthusiasm in the environmental community and significant, if sometimes hesitant, adoption 
Table 2. Diversification of land access and tenure arrangements.

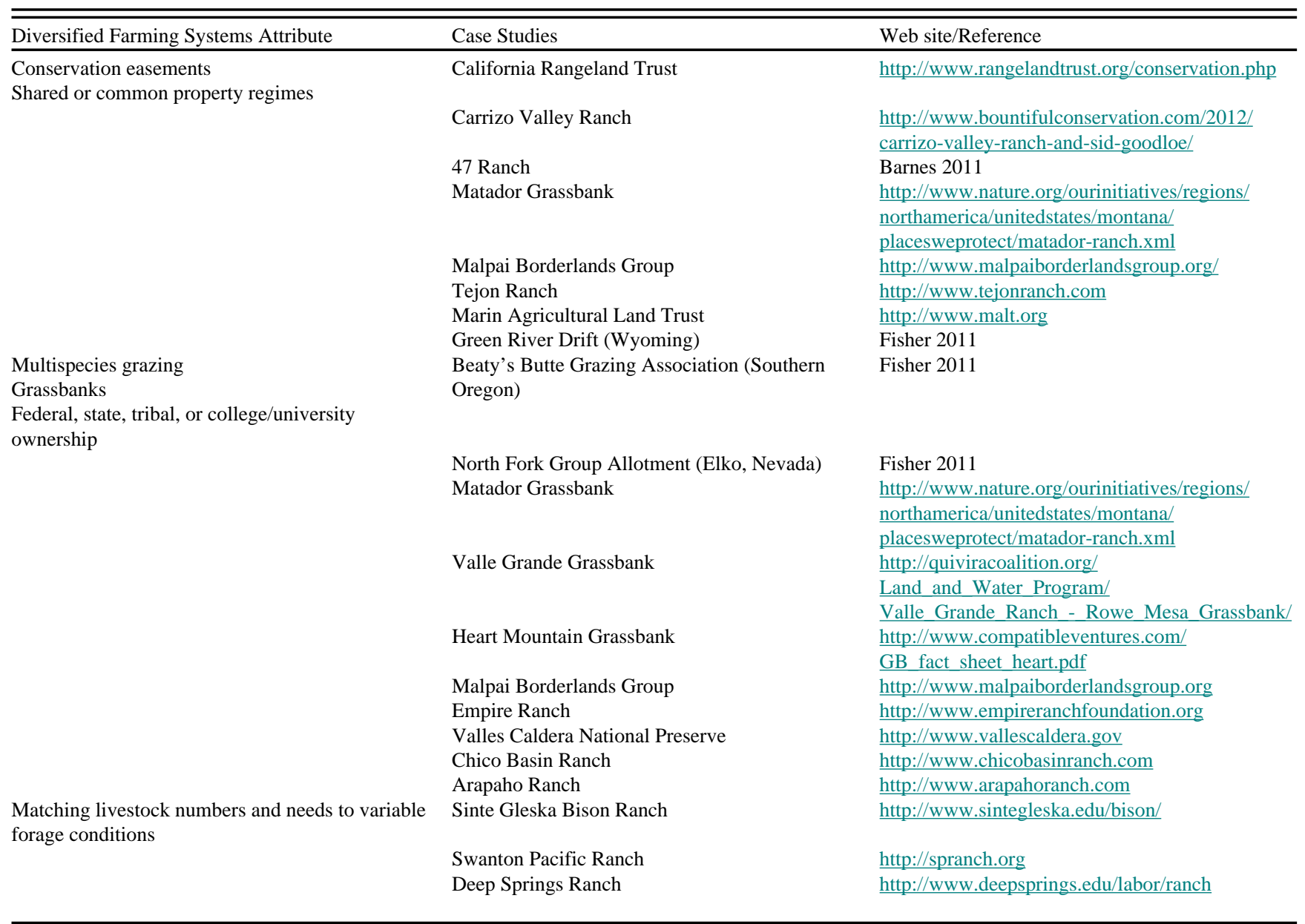

by ranchers (Rissman and Sayre 2012; Table 2). Conservation easements evolved from easements long used as a tool of land management for more specific purposes such as protecting rights of way, severed mineral title, and hunting (Merenlender et al. 2004). The concept was expanded to include a more general protection from development of lands with conservation value, and there is some evidence that since they began being used as a tool for conserving ranchland, conservation easements have become more flexible, or less precise in their requirements regarding grazing, over time (Rissman and Sayre 2012).

Conservation easements on ranches and other working lands are often purchased to buffer adjacent protected lands, and their details vary widely to accommodate the particular circumstances of landowners and easement holders alike (Rissman et al. 2007). Similarly, ranchers may sell habitat mitigation easements, or credits from mitigation banks, to public or private developers to offset damage caused by construction projects elsewhere (Bonnie 1999, Merenlender et al. 2004). For mixed-tenure ranchers, interest in easements often depends on the security of tenure to public grazing allotments, because loss of an allotment could leave a private parcel that is not viable for ranching by itself (Rissman and Sayre 2012). On their private lands, ranchers may also sign long-term leases for communication towers, oil and gas wells, hunting or wildlife observation access, and wind or solar energy development.

Ancient in origin but somewhat innovative in modern U.S. ranching are shared or common property regimes. Federal grazing allotments are sometimes leased by associations of up to 40 ranchers who run their stock in common. Taking advantage of the economy of scale in labor, because the amount of work required to husband 10 cows may be the same as is required to take care of 100 , these ranchers pool their cattle and collectively hire cowboys to take care of the animals. At the end of the grazing season, animals are sorted back out and moved home or to other pastures. For example, the Green River Drift in Wyoming is an association of ranchers that collectively moves cattle along a 70 mile stock driveway between summer and winter pasture, collecting animals on the 
way to a Forest Service allotment and redistributing them according to ownership on the way down in the fall ( $\mathrm{J}$. Magagna, personal communication). The Beatys Butte Grazing Association in southeast Oregon is a collection of ranchers who send cattle during the summer to a BLM allotment of roughly 200,000 ha and pool labor for gathering and sorting. On a smaller scale, the North Fork Group Allotment in Elko County, Nevada includes half a dozen cattle operations and two sheep ranchers. Grassbanks are another form of common pool resource, although they are used less regularly and by operators who do not necessarily act collectively. The "bank" is an area of rangeland set aside by a public agency or a conservation organization, with forage managed as an asset that can be lent to applicant ranchers to help support conservation practices such as drought destocking, prescribed fire, or grassland restoration (Gripne 2005, White and Conley 2007; Table 2).

\section{Diversification of products}

Since the mid-20th century, U.S. rangeland cattle production has been oriented toward the sale of a single commodity: calves destined for feedlots. The genetic diversity of beef cattle has been reduced dramatically because cattle buyers and processing firms demand animals of uniform size, color, and shape. More recently, however, many ranchers have diversified away from this norm to improve the sustainability of their operations. Mixed or minor breed cattle, e.g., Murray Gray, British White, Criollo, Loala, Belted Galloway, are the clearest instance of this type of diversification, but a number of ranchers also pursue greater genetic variability within conventional breeds, by culling for locally adapted herds, for example, smaller animals that thrive during drought or on limited available forage. Ranches may also raise multiple livestock species, e.g., sheep, goats, hogs, bison, chickens, ostriches, and llamas, that may include minor or mixed breeds as well. Rehoboth Ranch, 40 miles northeast of Dallas, Texas, combines these two strategies by raising Red Angus, Angus cross breed, and Red Devon cross breed cattle alongside pastured lamb, pork, and poultry (Table 3). Ranching with multiple species and breeds can provide ecological benefits, maximize forage utilization, and minimize producer risk (Barnes 2011).

Ranchers may also enter the market earlier in the animal life cycle by selling breeding stock to other producers, as Pharo Cattle Company does, or later by finishing and even marketing their own animals. The U.S. Department of Agriculture (USDA) does not currently track on-ranch animal finishing, but recent estimates of U.S. grass-fed beef production range from 50,000-100,000 head per year (Gwin 2009). Some ranchers have leased steers for rodeo use, returning them to the ranch for fattening on grass at the end of the rodeo season.
Ranchers who finish their own animals may also diversify into value-added animal products; Colorado's McNeil Ranch, for example, sells jerky, pet food, burritos, and tamales (Table 3).

Another source of potential income for ranchers is wildlife. Livestock and wildlife production can be highly compatible, and income generated from wildlife provides incentive for ranchers to manage and enhance wildlife habitat. Although in the U.S. wildlife is considered a public resource (Butler et al. 2005), private property access rights may give landowners de facto control over it (White 2000, Butler et al. 2005). Ranchers can earn income, and provide food for the table, from wildlife in a number of ways, including fees or guided tours for sightseeing, bird-watching, fishing, and hunting. There are two kinds of wildlife ranching that are common: fee hunting and wildlife husbandry (Butler et al. 2005). Fee hunting is based on charging for hunting access on daily, seasonal, annual, outfitter, or broker programs. Access may be granted for hunting one or multiple species. For wild game, the season and allowed take are usually regulated by state laws and game agencies. Fee hunting of exotic game can allow the landowner greater control over access and rates of harvest, because exotic animals are usually considered private livestock in the eyes of the law (Butler et al. 2005).

Wildlife farming or husbandry relies on exotic wildlife or wildlife descended from populations that became private before current game laws were put in place. For example, most American bison are in private ownership today, and there are large herds of private native elk. In this system, animals are confined by fences and are intensively husbanded with selective breeding, supplemental feeding, and veterinary treatment, but otherwise managed as wild (Butler et al. 2005). There is a growing market in North America and Europe for wild ungulate meat because it is perceived as healthier than industrially produced meats (White 2000). In the United States, native wildlife meat or by-products cannot legally be sold, but meat and by-products from exotic big game, considered livestock, may be marketed (Yorks 1989).

At Deseret Land and Livestock, although revenue from the production of domestic livestock is the foundation of the ranch, income generated from wildlife-based recreation, such as feebased big game hunting, waterfowl hunting, bird watching, and fishing, accounts for as much as $30 \%$ to $40 \%$ of yearly income (DLL 2008, McGinty et al. 2009). In a California survey of oak woodland landowners, less than $10 \%$ earned income from hunting, though $37 \%$ hunted for themselves or gave access to friends, and $21 \%$ of all landowners stated that hunting was an important reason to live in the oak woodlands. On the other hand, $45 \%$ stated that watching wildlife was an important reason to live there (Huntsinger et al. 2010b). 
Table 3. Diversification of products.

\begin{tabular}{|c|c|c|}
\hline Diversified Farming Systems Attribute & Case Studies & Web site/Reference \\
\hline \multirow[t]{10}{*}{ Mixed or minor breed cattle } & Carrizo Valley Ranch & $\begin{array}{l}\text { http://www.bountifulconservation.com/2012/ } \\
\text { carrizo-valley-ranch-and-sid-goodloe/ }\end{array}$ \\
\hline & 47 Ranch & Barnes 2011 \\
\hline & Pharo Cattle Company & http://pharocattle.com/ \\
\hline & Windsor Dairy & $\begin{array}{l}\text { http://ruralspin.com/2012/01/30/windsor-dairy- } \\
\text { colorado/ }\end{array}$ \\
\hline & Marin Sun Farms & http://www.marinsunfarms.com \\
\hline & Effertz EZ Ranch & http://www.loala.com \\
\hline & American Criollo Beef Association & http://www.leanandtenderbeef.com \\
\hline & Rehoboth Ranch & http://www.rehobothranch.com \\
\hline & Shire Gate Farm & http://www.shiregatefarm.com \\
\hline & Montana Grasslands Beef & http://montanagrasslandsbeef.com \\
\hline \multirow[t]{10}{*}{ Multiple livestock species } & Fox Fire Farms & http://www.foxfirefarms.com/ \\
\hline & 47 Ranch & Barnes 2011 \\
\hline & Polyface & http://www.polyfacefarms.com \\
\hline & James Ranch & http://www.jamesranch.net \\
\hline & Ladder Ranch & http://www.ladderranch.com \\
\hline & Marin Sun Farms & http://www.marinsunfarms.com \\
\hline & Parker Pastures & http://parkerlandmanagement.com \\
\hline & Rehoboth Ranch & http://www.rehobothranch.com \\
\hline & Meadows Family Farms & http://meadowsfamilyfarms.com \\
\hline & Arriola Sunshine Farm & http://www.arriolasunshinefarm.com/ \\
\hline \multirow[t]{7}{*}{ Breeding stock } & Pharo Cattle Company & http://pharocattle.com \\
\hline & Lasater Ranch & http://www.lasaterranch.com \\
\hline & Tamarack Lamb and Wool & http://tamaracksheep.com/ \\
\hline & Effertz EZ Ranch & http://www.loala.com \\
\hline & Matheson Farms & http://www.mathesonfarms.com \\
\hline & Montana Grasslands Beef & http://montanagrasslandsbeef.com \\
\hline & Arriola Sunshine Farm & http://www.arriolasunshinefarm.com/ \\
\hline \multirow{5}{*}{$\begin{array}{l}\text { Value-added animal products (pet food, jerky, } \\
\text { bacon, sausage, tamales) }\end{array}$} & JX Ranch Natural Beef & http://www.leannaturalbeef.com/about-us.htm \\
\hline & McNeil Ranch & http://www.grassfedandhealthy.com \\
\hline & Sinte Gleska Bison Ranch & http://www.sintegleska.edu/bison/ \\
\hline & Marin Sun Farms & http://www.marinsunfarms.com \\
\hline & Meadows Family Farm & http://meadowsfamilyfarms.com \\
\hline \multirow{13}{*}{$\begin{array}{l}\text { Nonmeat animals/animal products (dairy, eggs, } \\
\text { horses, dogs, leather, wool, dog bones, rodeo bulls) }\end{array}$} & JX Ranch Natural Beef & http://www.leannaturalbeef.com/about-us.htm \\
\hline & Fox Fire Farms & http://www.foxfirefarms.com/ \\
\hline & Tamarack Lamb and Wool & http://tamaracksheep.com/ \\
\hline & Windsor Dairy & $\begin{array}{l}\text { http://ruralspin.com/2012/01/30/windsor-dairy- } \\
\text { colorado/ }\end{array}$ \\
\hline & Polyface & http://www.polyfacefarms.com \\
\hline & James Ranch & http://www.jamesranch.net \\
\hline & Ladder Ranch & http://www.ladderranch.com \\
\hline & Hobo Ranch & http://www.hoboranches.com \\
\hline & Marin Sun Farms & http://www.marinsunfarms.com \\
\hline & Parker Pastures & http://parkerlandmanagement.com \\
\hline & Rehoboth Ranch & http://www.rehobothranch.com \\
\hline & Thunder Heart Bison & http://www.thunderheartbison.com \\
\hline & Arriola Sunshine Farm & http://www.arriolasunshinefarm.com/ \\
\hline \multirow{6}{*}{$\begin{array}{l}\text { Mixed crop and livestock (crops, honey, timber, } \\
\text { agricultural products, e.g., compost, feed) }\end{array}$} & Tamarack Lamb and Wool & http://tamaracksheep.com/ \\
\hline & Fox Fire Farms & http://www.foxfirefarms.com/ \\
\hline & James Ranch & http://www.jamesranch.net \\
\hline & Work Ranch & http://www.workranch.com \\
\hline & Tejon Ranch & http://www.tejonranch.com \\
\hline & Swanton Pacific Ranch & http://spranch.org \\
\hline
\end{tabular}




\begin{tabular}{|c|c|c|}
\hline \multirow{7}{*}{ Wood products } & Nicasio Native Grass Ranch & $\begin{array}{l}\text { http://www.marinorganic.org/producers/ } \\
\text { producers nicasio native.html }\end{array}$ \\
\hline & Shire Gate Farm & http://www.shiregatefarm.com \\
\hline & Meadows Family Farm & http://meadowsfamilyfarms.com \\
\hline & Thunder Heart Bison & http://www.thunderheartbison.com \\
\hline & Arriola Sunshine Farm & http://www.arriolasunshinefarm.com/ \\
\hline & Polyface & http://www.polyfacefarms.com \\
\hline & Swanton Pacific Ranch & http://spranch.org \\
\hline \multirow[t]{7}{*}{$\begin{array}{l}\text { Nonagricultural products (energy production, } \\
\text { mining, boats and trailers, merchandise, photos) }\end{array}$} & Carrizo Valley Ranch & $\begin{array}{l}\text { http://www.bountifulconservation.com/2012/ } \\
\text { carrizo-valley-ranch-and-sid-goodloe/ }\end{array}$ \\
\hline & 47 Ranch & Barnes 2011 \\
\hline & James Ranch & http://www.jamesranch.net \\
\hline & Lava Lake Lamb & http://www.lavalakelamb.com \\
\hline & McNeil Ranch & http://www.grassfedandhealthy.com \\
\hline & Tejon Ranch & http://www.tejonranch.com \\
\hline & Cherokee Hills Ranch & http://www.cherokeehillsranch.com \\
\hline
\end{tabular}

Some rangeland livestock producers also sell nonmeat animals, e.g., horses, dogs, rodeo steers or bulls, or nonmeat animal products, e.g., dairy, eggs, leather, wool, dog bones. Mixed crop and livestock operations, less common in the United States since World War II, may be making a comeback as well (Barbieri et al. 2008). Durango, Colorado's James Ranch, for example, sells raw milk, cheese, and eggs, as well as vegetables from their market garden. Potential benefits of this type of integrated crop and livestock production include nutrient cycling, risk spreading, and greater local food security.

A number of ranches produce wood products or nonagricultural products, e.g., oil and gas, renewable energy, minerals, photos, merchandise. The petroleum, mining, and forestry industries have historically relied heavily on both public and private rangelands, while renewable energy generation has emerged more recently as a nonagricultural source of ranch income. Ranches with agritourism enterprises may also sell photos or ranch-related merchandise.

\section{Diversification of markets and marketing}

Many practices that conserve diversity on ranches in the U.S. offer opportunities, and sometimes imperatives, to capture added value via alternative markets. Various third-party certification and marketing systems have emerged to help capture added value from niche markets such as grass-fed, organic, humane, local, predator-friendly, or wildlife-friendly. Certified Humane (www.certifiedhumane.org/) certifies 93 producers nationwide, American Grassfed Association (www. americangrassfed.org/) certifies 153 producers, and as of the last agricultural census (USDA-ERS 2010), 2.16 million acres of rangeland and pastureland were certified organic, as were 15.5 million poultry animals and nearly half a million head of cows, hogs, and sheep. Price premiums for niche meats can be $10 \%$ to $30 \%$ over conventional meat products (Gwin and Hardesty 2008), and although niche markets represent only $4.2 \%$ of total beef sales, that number has grown steadily, up from $1.1 \%$ in 2003 (Clause 2010, National Cattleman's Beef Association 2012).
Alternative marketing arrangements are growing to take advantage of these premiums. Cooperatives and producer marketing boards, as well as companies that source by contract from multiple operations, can help small-scale producers capture more downstream value, maintain ownership of new technologies, and give producers more market power than would otherwise be the case (Moran et al. 1996). They can also help producers access niche markets for locally produced or sustainable products. The Country Natural Beef cooperative, for example, enables 120 ranches in 12 states to sell on national and international markets under a brand that testifies to a common set of sustainability and animal welfare standards.

At the local and regional level, marketing strategies range from direct local sales to consumers, restaurants, and retail outlets, to farm stands, farmers' markets, local online sales, and local produce aggregation and delivery services. Door to Door Organics is a local produce aggregator serving Colorado, Kansas City, Michigan, and Chicago; McNeil Ranch sells its grass-fed beef through a members-only weight loss plan (Table 4). Direct to consumer food marketing grew $104 \%$ between 1997 and 2007, and 135\% in the Rocky Mountain and far Western states (USDA 2009a), with consumers increasingly endeavoring not only to "know their farmer" but their rancher as well. The number of farmers' markets has increased dramatically, with $16 \%$ growth from 2009 to 2010 and over 6100 markets currently in operation nationwide (USDA 2011). Additionally, the 2007 USDA agricultural census indicated that 12,549 farms in the United States market products via community supported agriculture (CSA) programs (USDA 2009b), although the true number may be significantly lower (Galt 2011). Many CSAs include meat, or deal exclusively with meat products, often based on ecologically sensitive production practices. Another means by which ranchers "put a face" on their products is the development of local and regional brands. Beef from Marin Sun Farms, in Point Reyes, California, for example, is sold exclusively in the San Francisco Bay Area under the ranch's 
Table 4. Diversification of markets and marketing

\begin{tabular}{|c|c|c|}
\hline Diversified Farming Systems Attribute & Case Studies & Web site/Reference \\
\hline Third party certification and marketing & $\begin{array}{l}\text { American Grassfed Association certified } \\
\text { producers } \\
\text { Eatwild Directory of grassfed meat and dairy } \\
\text { Certified Humane } \\
\text { Arapaho Ranch }\end{array}$ & $\begin{array}{l}\text { http://www.americangrassfed.org/producer- } \\
\text { profiles/ } \\
\text { http://www.eatwild.com/products/index.html } \\
\text { http://www.certifiedhumane.org/ } \\
\text { http://www.arapahoranch.com }\end{array}$ \\
\hline Cooperatives and producer marketing boards & $\begin{array}{l}\text { Country Natural Beef } \\
\text { Mountain States Lamb } \\
\text { Pharo Cattle Company } \\
\text { Grassfed Livestock Alliance }\end{array}$ & $\begin{array}{l}\underline{\text { http://www.countrynaturalbeef.com/story.php }} \\
\text { http://www.mslamb.com/ } \\
\text { http://pharocattle.com } \\
\text { http://www.grassfedlivestockalliance.com }\end{array}$ \\
\hline Direct to consumer food marketing (farmers' & Eatwild & http://www.eatwild.com/products/index.html \\
\hline
\end{tabular}

markets, community supported agriculture, retail operation, mail order, restaurants, institutions, weight loss programs)

Local and regional brands

American Grassfed Association
JX Ranch Natural Beef
Blue Range Ranch
Carrizo Valley Ranch
Tamarack Lamb and Wool
Fox Fire Farms
Windsor Dairy
47 Ranch
Polyface
James Ranch
Lava Lake Lamb
Ranney Ranch
Hobo Ranch
McNeil Ranch
Sinte Gleska Bison Ranch
Swanton Pacific Ranch
Marin Sun Farms
Parker Land Management
Rehoboth Ranch
Blue Range Ranch
Fox Fire Farms
Lava Lake Lamb
Marin Sun Farms
Thunder Heart Bison
Arriola Sunshine Farm

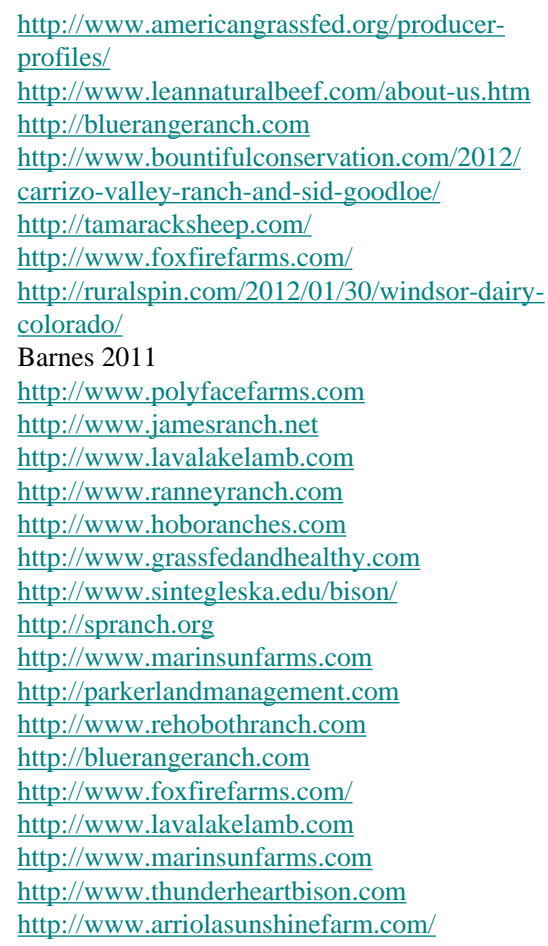

own label, which highlights grass-fed and sustainable practices. The company contracts for products from multiple operations in the region to take advantage of differing prime harvest times for their products.

\section{Diversification of services}

There is a long history of Western ranches providing agricultural tourism and recreation related services for payment, most famously on 'dude' ranches where visitors pay to ride horses and experience the mythic ranching lifestyle. Many ranches sell access to their private lands for horse riding or boarding, and a growing number support education and research. The Deseret Land and Livestock Company combines these classic service diversification strategies, providing guided fishing, bird-watching, and natural history tours, offering a mix of fee and free hunting access, and hosting researchers and educational groups (Table 5).

Other marketable services have emerged more recently. One prominent example is grazing for control of fire risk and invasive weeds. Companies have sprung up offering to provide goats specifically for vegetation management, and they may charge as much as US\$160/ha for this service (Table 5). Goats will consume some invasive species that other livestock refuse, and they like brush, which can be invasive on rangelands. Ranchers who traditionally produced only cattle now may acquire herds of goats specifically to rent out. Cattle can also be used for fire hazard management; in fact, one reason cited by public agencies for permitting grazing on their lands is reduction of fuel loads. However, in these cases cattle 
Table 5. Diversification of services.

\begin{tabular}{|c|c|c|}
\hline Diversified Farming Systems Attribute & Case Studies & Web site/Reference \\
\hline \multirow{15}{*}{$\begin{array}{l}\text { Agricultural tourism and recreation (including } \\
\text { rodeo, filming) }\end{array}$} & JX Ranch Natural Beef & http://www.leannaturalbeef.com/about-us.htm \\
\hline & Diablo Trust & http://www.diablotrust.org \\
\hline & Deseret Land and Livestock Company & http://www.dlandl.com \\
\hline & Fox Fire Farms & http://www.foxfirefarms.com/ \\
\hline & Polyface & http://www.polyfacefarms.com \\
\hline & James Ranch & http://www.jamesranch.net \\
\hline & Ladder Ranch & http://www.ladderranch.com \\
\hline & Work Ranch & http://www.workranch.com \\
\hline & Empire Ranch & http://www.empireranchfoundation.org \\
\hline & Valles Caldera National Preserve & http://www.vallescaldera.gov \\
\hline & Chico Basin Ranch & http://www.chicobasinranch.com \\
\hline & Tejon Ranch & http://www.tejonranch.com \\
\hline & Marin Sun Farms & http://www.marinsunfarms.com \\
\hline & Madroño Ranch & http://madronoranch.com \\
\hline & Rainstein Ranch & http://www.reinsteinranch.com \\
\hline \multirow[t]{6}{*}{ Hunting and fishing } & Carrizo Valley Ranch & $\begin{array}{l}\text { http://www.bountifulconservation.com/2012/ } \\
\text { carrizo-valley-ranch-and-sid-goodloe/ }\end{array}$ \\
\hline & Deseret Land and Livestock Company & http://www.dlandl.com \\
\hline & Ladder Ranch & http://www.ladderranch.com \\
\hline & Valles Caldera National Preserve & http://www.vallescaldera.gov \\
\hline & Tejon Ranch & http://www.tejonranch.com \\
\hline & Madroño Ranch & http://madronoranch.com \\
\hline \multirow[t]{4}{*}{ Horse boarding } & Work Ranch & http://www.workranch.com \\
\hline & Tejon Ranch & http://www.tejonranch.com \\
\hline & Reinstein Ranch & http://www.reinsteinranch.com \\
\hline & Cherokee Hills Ranch & http://www.cherokeehillsranch.com \\
\hline \multirow[t]{21}{*}{ Education and research } & Blue Range Ranch & http://bluerangeranch.com \\
\hline & Diablo Trust & http://www.diablotrust.org \\
\hline & Deseret Land and Livestock Company & http://www.dlandl.com \\
\hline & 47 Ranch & Barnes 2011 \\
\hline & CARLY Ranch Apprentice Program & http://quiviracoalition.org/ \\
\hline & & $\begin{array}{l}\text { Capacity Building Mentorship/ } \\
\text { CARLY Ranch Apprentice Program /index. } \\
\text { html }\end{array}$ \\
\hline & Polyface & http://www.polyfacefarms.com \\
\hline & James Ranch & http://www.jamesranch.net \\
\hline & Lava Lake Lamb & http://www.lavalakelamb.com \\
\hline & Work Ranch & http://www.workranch.com \\
\hline & Empire Ranch & http://www.empireranchfoundation.org \\
\hline & Malpai Borderlands Group & http://www.malpaiborderlandsgroup.org/ \\
\hline & Ute Creek Cattle Company & http://www.utecreekcattlecompany.com \\
\hline & Wind River Ranch & http://windriverranch.org \\
\hline & Valles Caldera National Preserve & http://www.vallescaldera.gov \\
\hline & Chico Basin Ranch & http://www.chicobasinranch.com \\
\hline & Tejon Ranch & http://www.tejonranch.com \\
\hline & Sinte Gleska Bison Ranch & http://www.sintegleska.edu/bison/ \\
\hline & Swanton Pacific Ranch & http://spranch.org \\
\hline & Deep Springs Ranch & http://www.deepsprings.edu/labor/ranch \\
\hline & Nicasio Native Grass Ranch & $\begin{array}{l}\text { http://www.marinorganic.org/producers/ } \\
\text { producers nicasio native.html }\end{array}$ \\
\hline \multirow[t]{4}{*}{ Control of fire risk and invasive weeds } & Livestock for Landscapes & http://www.livestockforlandscapes.com \\
\hline & Goats R Us & http://www.goatsrus.com \\
\hline & Blue Range Ranch & http://bluerangeranch.com \\
\hline & Rocky Mountain Woolly Weeders & http://woolyweeders.com/ \\
\hline $\begin{array}{l}\text { Services for other ranchers (consulting, monitoring, } \\
\text { video production, cow horse training facilities) }\end{array}$ & Matheson Farms & http://www.mathesonfarms.com \\
\hline
\end{tabular}


Habitat for wildlife, pollinators, and plants

Carbon storage and sequestration

Restoration

Cultural preservation
American GrazingLands Services

Pharo Cattle Company

Arriola Sunshine Farm

JX Ranch Natural Beef

Blue Range Ranch

Three Creeks Ranch

Diablo Trust

Deseret Land and Livestock Company

Lasater Ranch

Ute Creek Cattle Company

Malpai Borderlands Group

Wind River Ranch

Valles Caldera National Preserve

Chico Basin Ranch

Tejon Ranch

Nicasio Native Grass Ranch

Blue Range Ranch

Carrizo Valley Ranch

Rafter F Cattle Company

Diablo Trust

Windsor Dairy

Malpai Borderlands Group

Ute Creek Cattle Company

Wind River Ranch

Devil's Spring Ranch

Deseret Land and Livestock Company

47 Ranch

Wind River Ranch

Arapaho Ranch

Sinte Gleska Bison Ranch http://www.americangrazinglands.com http://www.pharocattle.com

http://www.arriolasunshinefarm.com/ http://www.leannaturalbeef.com/about-us.htm

http://bluerangeranch.com

http://www.sandcounty.net/initiatives/LCA/

Winners/CA/?ID=159

http://www.diablotrust.org

http://www.dlandl.com

http://www.lasaterranch.com

http://www.utecreekcattlecompany.com

http://www.malpaiborderlandsgroup.org/

http://windriverranch.org

http://www.vallescaldera.gov

http://www.chicobasinranch.com

http://www.tejonranch.com

http://www.marinorganic.org/producers/

producers nicasio native.html

http://bluerangeranch.com

http://www.bountifulconservation.com/2012/

carrizo-valley-ranch-and-sid-goodloe/

http://www.theshiftofland.org/interviews/roger-

bowel

http://www.diablotrust.org

http://ruralspin.com/2012/01/30/windsor-dairycolorado/

http://www.malpaiborderlandsgroup.org/

http://www.utecreekcattlecompany.com

http://windriverranch.org

http://www.trilliuminvest.com/news-articles-

category/advocacy-news-articles/rest oring-newmexico\%E2\% $80 \% 99$ s-natural-gas-fields/

http://www.dlandl.com

Barnes 2011

http://windriverranch.org

http://www.arapahoranch.com

http://www.sintegleska.edu/bison/ owners usually pay for the privilege of grazing grass even if reduced fire hazard is a recognized service. Finally, ranchers may also sell services for other ranchers. For example, the Arrow T Ranch in Conifer, Colorado, provides cow-horse training facilities, while Whatcom County's Matheson Farms offers consulting, monitoring, group facilitation, and even video production (Table 5).

Ranches also produce a wide variety of ecosystem services that are more difficult to sell, but of growing interest and importance (Havstad et al. 2007, Toombs et al. 2011). Some are produced incidentally, as by-products of range livestock production; others are produced intentionally by ranchers for personal and public consumption. As the demand to protect and increase ecosystem services grows, and competition for land intensifies, rancher interest in being compensated for ecosystem services as a way of diversifying their income streams will likely increase.

Of the ecosystem services that benefit the public, those provided at the landscape scale are the most universally appreciated. The "wide open spaces" of ranch country are a cherished part of the quality of life in the United States. Because range livestock production typically requires a lot of land to support enough stock for a livelihood, ranches tend to be extensive; because it does not generally require cultivation and conversion of ecosystems, the land looks unaltered to most people, even though it is being managed and used for agricultural production. As large, unfragmented, and relatively intact landscapes, rangelands provide habitat for wildlife, pollinators, and plants, as well as watershed functioning and carbon storage and sequestration, among other services (White 2010, Gosnell et al. 2011 a, 2011 b, Maczko et al. 2011). In much of the West, ranch lands serve to buffer parks and reserves from more intensively settled areas (Maestas et al. 2003) and may play an active role in restoration projects.

Within the ranch, at the pasture scale, the priorities, practices, and trade-offs among ecosystem services become more complex. Although large-scale ecosystem functions are less altered in ranching than in other forms of agriculture, livestock production has short- and long-term impacts on the land: grass 
and water are consumed, trails and fences are created, and soils may be affected. Some types of vegetation and wildlife may flourish as a result, whereas others may decline. Increasingly, though, livestock producers are finding that grazing can be used as a tool to create vegetation and soil conditions that favor the coproduction of various ecosystem services.

Most recently, the value of California rangelands for pollination services, as habitat for wild bees that pollinate a third or more of the state's crops, has been estimated at between US\$937 million and US\$2.4 billion (Chaplin-Kramer et al. 2011). Pollinators can be managed at the landscape scale by keeping ranches intact and hence, large swaths of land unfragmented, which provides refuge and habitat for large numbers of pollinators. At the pasture scale, on some ecological sites, grazing can be managed to benefit the broadleaved plants, i.e., flowers that pollinators need.

Many other examples can be adduced, albeit without dollar estimates of their values. In the San Francisco Bay region, half of the available habitat for the endangered California tiger salamander (Ambystoma californiense) is provided by stock ponds managed by ranchers. In this case, grazing seems to benefit the animals (DiDonato 2007), as it does in the vernal pools that are its native habitat (Marty 2005, Pyke and Marty 2005). In a more complex case, more than half of the habitat for the state-threatened California Black Rail (Laterallus jamaicensis) comes from leaky ponds, irrigation ditches, and troughs associated with ranching (Richmond et al. 2010), although at the pasture scale, grazing must be managed so as not to change the structure of the vegetation in the small mesic areas that are the rail's habitat during the nesting season. The threatened Chiricahua leopard frog (Rana chiricahuensis) has declined with the loss of natural perennial surface waters and the spread of the bullfrog (Lithobates catesbeianus), which is a predator of it. It persists primarily in refugia in ranch stock tanks, which provide perennial habitat discontinuous from bullfrog-invaded streams (USDI-FWS 2002). Other examples of habitat improvement with grazing include burrowing owls (Athene cunicularia; Green and Anthony 1989), endangered kangaroo rats (Genus Dipodomys; Kelt et al. 2005), and butterflies (Weiss 1999). There have been notable cases where grazing exclusion has caused the species being protected by the exclusion to leave or disappear (Weiss 1999, DiDonato 2007).

Ranchers have captured some of the value of these services through federal cost-share and incentives programs that are in fact payment for ecosystem services opportunities for ranchers. These include the Working Lands Programs funded through the U.S. Farm Bill's Title II: Conservation, and administered by the Department of Agriculture's Natural Resource Conservation Service (USDA-NRCS 2012). The Environmental Quality Incentives Program (EQIP), the Conservation Stewardship Program (CSP), and the Wildlife
Habitat Incentives Program (WHIP) are among those that apply broadly to rangelands. EQIP provides technical assistance (www.ers.usda.gov/farmbill/2008/titles/titleIIConservation. htm\#technical), cost-share payments (www.ers.usda.gov/ briefing/farmpolicy/glossary.htm\#costshare), and incentive payments (www.ers.usda.gov/briefing/farmpolicy/glossary. htm\#incentive) to assist crop and livestock producers with environmental and conservation improvements on land used for agricultural production. For example, a rancher wanting to repair a stock pond or put in a trough can apply for cost share funds to carry out the work in an environmentally sensitive way. The CSP provides payments to producers for adopting or maintaining conservation management practices that address one or more resources of concern, such as soil, water, and wildlife habitat. WHIP (www.ers.usda.gov/ briefing/farmpolicy/glossary.htm\#whip) provides technical assistance and cost sharing for development and improvement of wildlife habitat. The USDA NRCS administers these programs. About US\$61 million were obligated through WHIP, US\$864 million through EQIP, and US\$191 million though CSP in 2011 to ranchers and farmers (USDA-NRCS 2012). The Farm and Rangeland Protection Program provides funds to eligible entities, i.e., state, tribal, or local governments and nonprofit organizations, to help purchase easements (www.ers.usda.gov/briefing/farmpolicy/glossary.htm\#easements) that would preclude nonfarm development of productive farm and ranch land. About US\$161 million was provided for conservation easements in 2011.

\section{Obstacles and policy recommendations}

It is clear from this brief review that rangelands are significant sites for agricultural diversification in the western U.S. Innovative ranchers have found ways to persist under uncertain economic and ecological conditions. Numerous barriers remain to be overcome, however, if these innovations are to move from the margins to the mainstream.

In many parts of the country, the largest barrier to diversified marketing, especially for small to midsized ranches, is the lack of accessible USDA certified processing facilities (Barnes 2011, Niche Meat Processor Assistance Network 2012). The U.S. beef packing industry is one of the most concentrated in American agriculture: four companies control $83.5 \%$ of the total market (Hendrickson and Heffernan 2007). Many commercial slaughtering facilities will not process small batches of locally finished cattle, or smaller than standard cattle. This can preclude ranchers from selling directly to local customers, or from diversifying the genetics of their herds. Criollo cattle, for example, travel farther from water sources and consume more diverse vegetation types, and ranchers also claim the breed is more adapted to heat stress. However, cattle adapted to arid lands are typically several hundred pounds smaller than conventional, mostly British, breeds (Barnes 2011). Policies to certify and support smaller processing facilities would help more ranchers diversify in these ways. 
Uncertainty around land tenure can also inhibit diversification by discouraging long-term investments in alternative production or marketing. On private land, encroachment of other land uses, residential, commercial, industrial, or energyrelated, can directly disrupt seasonal leasehold tenure, and it also indirectly complicates ranch management and may inhibit or preclude range improvement projects, e.g., prescribed fire. Associated rising land values make it more likely that ranchers will sell out or evaluate decisions on shorter timeframes. Urbanization can lead to "impermanence syndrome," decreasing investment and limiting management intensity if ranchers believe their land will ultimately be sold for nonagricultural purposes (Berry and Plaut 1978, Heimlich and Anderson 1987, Liffman et al. 2000, Huntsinger et al. 2010b). On public lands, meanwhile, uncertainty of renewal of leases similarly inhibits investments in innovation, and may prevent ranchers from considering conservation easements on their private parcels.

The importance of scale in the ability of a ranching operation to diversify should not be underestimated. Large enterprises are more likely to be able to use a wider range of opportunities in the face of tenure changes and regionally variable precipitation. Flexible stocking carries an increased economic risk (Torell et al. 2010) that can be better absorbed by larger firms. The flexibility in stocking rates advocated by the recent Conservation Benefits of Rangeland Practices (Briske 2011) and increasingly demanded by the management objectives of public and private landowners may only be possible with rancher collectives pooling animals and land resources in the whole ranch concept, or achieved by single operations that cover multiple climate zones and have the ability to move truckloads of cattle on short notice.

Policies to stabilize land use and land tenure arrangements through tax incentives, such as California's Williamson Act, can help provide ranchers with the long-term confidence to diversify. Passed in 1965, and historically applied to over half of California's farm and ranch lands, this program has recently suffered the loss of state funding (California Department of Conservation 2012). The Williamson Act provided tax relief to farmers and ranchers who agreed to keep their land out of development for at least ten years via a rolling contract. It did not prevent, unfortunately, conversion to intensive agriculture such as vineyards, a common competitor for rangelands in the state. In California as elsewhere, then, local governments are key players in forging policies and partnerships to protect rangelands for open space and associated ecosystem values (Resnik et al. 2006). Surprisingly, the recent economic downturn appears to have helped, or at least not slowed, the rapid growth in conservation easement acquisition by local and regional land trusts, as development pressure has ebbed and land prices have dropped (Christensen et al. 2011).

High rates of landowner turnover pose additional challenges to ranch and rangeland conservation. Even where ranches are being purchased by investors or so-called amenity buyers who do not intend to subdivide their properties, turnover can undermine customary arrangements regarding access for livestock movement, hunting, or other DFS-related activities (Theobald et al. 1996, Gosnell et al. 2006, Haggerty and Travis 2006, Yung and Belsky 2007). Amenity buyers, who do not depend on livestock for their livelihoods, may discontinue grazing and thereby reduce the viability of local or regional support services, e.g., veterinary care, animal supply stores, on which active ranchers depend (Brunson and Huntsinger 2008), or disrupt established systems of wildlife management, with impacts on neighboring ranchers, especially where hunting or fishing are important revenue sources (Haggerty and Travis 2006). On the other hand, amenity buyers who choose to cooperate with local ranchers can bring valuable knowledge, skills, resources, and ideas to collaborative rangeland conservation efforts (Sayre 2005).

At landscape scales, collaboration among ranchers, and between ranchers, agencies, and environmental groups, can help promote innovative management practices and rangeland DFS (Sayre 2005, York and Schoon 2011). Implementing substantive management changes can be risky, expensive, and require several years to succeed, and supportive programs and cooperative networks of ranchers, agencies, technical advisors, and NGOs can greatly improve the likelihood of rangeland DFS innovations (Provenza 2003, Kennedy and Brunson 2007, Brunson and Burritt 2009). Local flexibility and collaboration from federal agencies can help increase diversified management practices spatially, though initiatives like grassbanking, temporally, through matching livestock numbers and needs to variable forage conditions, and at the patch or pasture scale, through adaptive, monitoring-based habitat management. Coordinated management of the mosaic of unfragmented public and private land is a practical challenge, but it can help conserve landscape scale ecosystem processes, especially where rangelands persist with minimal fragmentation by urban or ex-urban development (Sayre 2005). Habitat conservation plans to meet regulatory requirements for endangered species can also be more readily undertaken at the scale of multiple ranches working collaboratively with the relevant wildlife agencies.

Markets and incentives for production of ecosystem services have the potential to make profound changes in ranches and ranching. At present, most ranch enterprises have little chance of capturing these values in monetary terms other than by selling the land at inflated values, i.e., far in excess of what livestock production can economically justify. Conservation easements that provide some compensation for keeping land open are the main opportunities for marketing the ecosystem services of ranching landscapes today, whereas tax relief programs offer some incentives to those who do not develop. A few ranchers are marketing or getting payments in the form of government cost-shares for ecological restoration, carbon 
sequestration, and provision of habitat (Gosnell et al. 2011b; Table 1), but more research is needed to understand the complex ecological processes that support the production of clean air and water, wildlife habitat, carbon sequestration, recreation, and amenity values associated with extensive, unfragmented rangelands (de Steiguer et al. 2008). Policy frameworks for remunerating land managers who successfully provide these public goods and services are still in their infancy, but may represent important ways of sustaining rangelands and encouraging diversification.

On the other hand, many ranchers, and farmers, complain that regulations are excessively complex, inefficient, and sometimes inconsistent (G. Humiston, personal communication). In a California survey, more than $80 \%$ of ranchers reported that over-regulation was an important reason to quit ranching; a Colorado survey indicated regulation was the second most common "reason to sell the ranch" (Liffman et al. 2000, Rowe et al. 2001). Many ranchers state that if they were paid for it, they could produce all the plants and animals that society desires to see conserved. Instead, however, the threat of regulation may cause some of them to avoid contact with anyone who might bring the resources, habitats, or species on their ranches to the attention of authorities, and they often feel burdened with an unfair share of the cost of maintaining and protecting regulated ecosystem services.

\section{CONCLUSIONS}

Rangeland livestock production is an important form of diversified agriculture. The delinking of crop and livestock production is a central feature of industrial agriculture and a major reason that the U.S. meat industry has become so unsustainable (Naylor et al. 2005). To be sure, farming and ranching are often geographically, discursively, and socially separated. But successful DFS must find ways to overcome these rifts. One way to begin is to conceive ranching and farming along a gradient of management intensity. From this perspective, ranching is a potential model for diversified farming because of its tight coupling of ecological and economic processes and the innovations that this coupling has provoked across a wide variety of highly biodiverse ecosystems (White 2008, Knight and White 2009). Some of the innovative strategies we have described here seem to push ranching further along the gradient toward farming: land is divided by fences, animals are more closely controlled and manipulated, and management intensity increases. Nevertheless, ranching survives by keeping costs low and letting a diversity of plants, animals, and ecosystems do the work, so to speak, and these are principles that can also be applied to farming.

Because of their long-term experience with large, highly variable and complex landscapes, many ranchers possess local ecological knowledge that can contribute unique insights regarding rangeland health and management (Knapp and Fernandez-Gimenez 2009). Rancher local knowledge can complement scientific knowledge to produce site-specific information on management practices and ecological responses (Knapp and Fernandez-Gimenez 2009) and thus provide the basis for diversified, locally adapted management. This knowledge base is threatened, however, as livestock profitability stagnates, land values climb, and ranchlands are converted to residential and other uses with higher economic returns. Land use change currently poses the greatest threat to rangeland biodiversity (Havstad and Peters 1999), and cultural preservation of ranching traditions and land-based livelihoods thus constitutes a significant cobenefit for society (Table 1).

Previous research has shown that most ranches are already managed for a variety of goals (Gentner and Tanaka 2002). Ranchers rarely identify profit as a primary motivation for ranching, instead, they cite the benefits of a place to raise a family, enjoy nature, make decisions autonomously, and work with animals (Liffman et al. 2000, Torell and Bailey 2000, Rowe et al. 2001). Such "multiple goal" ranchers make decisions that reflect their own personal balance of financial returns and the other benefits of ranching (Campos et al. 2009). Efforts to encourage further diversification of ranching goals and practices must be cognizant of this core set of ranching values, sometimes termed "ranch fundamentalism" (Smith and Martin 1972, Liffman et al. 2000). Far from an obstacle to DFS, ranchers' values represent an opportunity, because they seek ways to enhance the ecological processes on which they, their livestock, and range ecosystems as a whole all depend.

In summary, many ranchers are already involved in diversified agriculture, intentionally and incidentally. More will follow with the appropriate incentives, technical assistance, and education. Ranchers have responded well to education programs (Kennedy and Brunson 2007, Huntsinger et al. $2010 \mathrm{~b}$ ), and they have often expressed a desire for more direct, one-on-one technical assistance. Such incentives, coupled with ranch fundamentalism, may have a multiplicative, rather than only additional, effect on ranchers' stewardship. This is a positive social-ecological feedback with great potential for the environment.

Responses to this article can be read online at: http://www.ecologyandsociety.org/issues/responses. php/4790

\section{Acknowledgments:}

We are grateful to C. Kremen, A. Iles, C. Bacon, and the Diversified Farming Systems Roundtable at UC-Berkeley for their support of this project and for valuable feedback on earlier versions. We also thank two anonymous reviewers for their constructive suggestions for improvement. We remain responsible for the final product. 


\section{LITERATURE CITED}

Barbieri, C., E. Mahoney, and L. Butler. 2008. Understanding the nature and extent of farm and ranch diversification in North America. Rural Sociology 73(2):205-229.

Barnes, M. 2011. Low-input grassfed livestock production in the American West: case studies of ecological, economic, and social resilience. Rangelands 33(2):31-40. http://dx.doi. org/10.2111/1551-501X-33.2.31

Berry, D., and T. Plaut. 1978. Retaining agricultural activities under urban pressure: a review of land use conflicts and policies. Policy Sciences 9(2):153-178. http://dx.doi. org/10.1007/BF00143740

Bonnie, R. 1999. Endangered species mitigation banking: promoting recovery through habitat conservation planning under the Endangered Species Act. Science of the Total Environment 240:11-19. http://dx.doi.org/10.1016/S0048-9697 (99)00315-0

Briske, D. D., editor. 2011. Conservation benefits of rangeland practices: assessment, recommendations, and knowledge gaps. United States Department of Agriculture, Natural Resources Conservation Service, Washington, D.C., USA.

Briske, D. D., J. D. Derner, J. R. Brown, S. D. Fuhlendorf, W. R. Teague, K. M. Havstad, R. L. Gillen, A. J. Ash, and W. D. Williams. 2008. Rotational grazing on rangelands: reconciliation of perception and experimental evidence. Rangeland Ecology \& Management 61:3-17. http://dx.doi. org/10.2111/06-159R.1

Briske, D. D., N. F. Sayre, L. Huntsinger, M. FernandezGimenez, B. Budd, and J. D. Derner. 2011. Origin, persistence, and resolution of the rotational grazing debate: integrating human dimensions into rangeland research. Rangeland Ecology \& Management 64(4):325-334. http://dx.doi. org/10.2111/REM-D-10-00084.1

Brown, D. G., K. M. Johnson, T. R. Loveland, and D. M. Theobald. 2005. Rural land-use trends in the conterminous United States, 1950-2000. Ecological Applications 15 (6):1851-1863. http://dx.doi.org/10.1890/03-5220

Brunson, M. W., and E. A. Burritt. 2009. Behavioral factors in rotational grazing systems. Rangelands 31(5):20-25. http:// dx.doi.org/10.2111/1551-501X-31.5.20

Brunson, M. W., and L. Huntsinger. 2008. Ranching as a conservation strategy: can old ranchers save the new west? RangelandEcology \& Management 61:137-147. http://dx.doi. org/10.2111/07-063.1

Butler, M. J., A. P. Teaschner, W. B. Ballard, and B. K. McGee. 2005. Commentary: wildlife ranching in North Americaarguments, issues, and perspectives. Wildlife Society Bulletin
33:381-389. http://dx.doi.org/10.2193/0091-7648(2005)33 [381:CWRINA]2.0.CO;2

California Department of Conservation. 2012. Williamson Act program. California Department of Conservation, Sacramento, California, USA. [online] URL: http://www.conservation.ca. gov/dlrp/lca

Campos, P., J. L. Oviedo, A. Caparrós, L. Huntsinger, and I Coelho. 2009. Contingent valuation of woodland-owners private amenities in Spain, Portugal, and California. Rangeland Ecology \& Management. 62 (3):240-252 http://dx. doi.org/10.2111/08-178R2.1

Chaplin-Kramer, R., K. Tuxen-Bettman, and C. Kremen. 2011. Value of wildland habitat for supplying pollination services to Californian agriculture. Rangelands 33:33-41. http://dx.doi.org/10.2111/1551-501X-33.3.33

Christensen, J., J. Rempel, and J. Burr. 2011. Land trusts thrive despite, and because of, the Great Recession. High Country News, 12 December. [online] URL: http://www.hcn.org/ issues/43.21/land-trusts-thrive-despite-and-because-of-the-greatrecession

Clause, R. 2010. Natural beef profile. Agricultural Marketing Resource Center, U.S. Department of Agriculture, Washington, D.C., USA. [online] URL: http://www.agmrc. org/commodities products/livestock/beef/natural beef profile. $\underline{\mathrm{cfm}}$

de Steiguer, J. E., J. R. Brown, and J. Thorpe. 2008. Contributing to the mitigation of climate change using rangeland management. Rangelands 30(3):7-11. http://dx.doi. org/10.2111/1551-501X(2008)30[7:CTTMOC]2.0.CO;2

Deseret Land and Livestock (DLL). 2008. Ranch history. DLL, Woods Cross, Utah, USA. [online] URL: http://www. dlandl.com/pages/RanchHistory/index.html

DiDonato, J. 2007. Endangered amphibian research within grazed grasslands. Keeping Landscapes Working, A University California Cooperative Extension Newsletter for Rangeland Managers Winter:4-6.

Fuhlendorf, S. D., and D. M. Engle. 2001. Restoring heterogeneity on rangelands: ecosystem management based on evolutionary grazing patterns. Bioscience 51(8):625-632. http://dx.doi.org/10.1641/0006-3568(2001)051[0625:RHOREM] 2.0.CO;2

Galt, R. E. 2011. Counting and mapping community supported agriculture (GSA) in the United States and California: contributions from critical cartography/GIS. ACME: An International E-Journal for Critical Geographies 10 (2):131-162. 
Gentner, B. G., and J. A. Tanaka. 2002. Classifying federal public land grazing permittees. Journal of Range Management 55:2-11. http://dx.doi.org/10.2307/4003256

Goldstein, J. H., C. K. Presnall, L. Lopez-Hoffman, G. P. Nabhan, R. L. Knight, G. B. Ruyle, and T. P. Toombs. 2011. Beef and beyond: paying for ecosystem services on Western U.S. rangelands. Rangelands 33(5):4-12. http://dx.doi. org/10.2111/1551-501X-33.5.4

Gosnell, H., J. H. Haggerty, and W. R. Travis. 2006. Ranchland ownership change in the greater Yellowstone ecosystem, 1990-2001: implications for conservation. Society \& Natural Resources 19:743-758. http://dx.doi. org/10.1080/08941920600801181

Gosnell, H., N. Robinson-Maness, and S. Charnley. $2011 a$. Engaging ranchers in market-based approaches to climate change mitigation: opportunities, challenges, and policy implications. Rangelands 33(5):20-24. http://dx.doi. org/10.2111/1551-501X-33.5.20

Gosnell, H., N. Robinson-Maness, and S. Charnley. $2011 b$. Profiting from the sale of carbon offsets: a case study of the Trigg Ranch. Rangelands 33(5):25-29. http://dx.doi. org/10.2111/1551-501X-33.5.25

Government Accountability Office (GAO). 2005. Livestock grazing: federal expenditures and receipts vary, depending on the agency and the purpose of the fee charged. GAO-05-869. GAO, Washington, D.C., USA. [online] URL: http://www. gao.gov/new.items/d05869.pdf

Green, A. G., and R. G. Anthony. 1989. Nesting success and habitat relationships of Burrowing Owls in the Columbia basin, Oregon. Condor 91:347-354. http://dx.doi.org/10.2307/1368313

Gripne, S. L. 2005. Grassbanks: bartering for conservation. Rangelands 27:24-28. http://dx.doi.org/10.2111/1551-501X (2005) $27<24: \mathrm{GBFC}>2.0 . \mathrm{CO} ; 2$

Gwin, L. 2006. New pastures, new food: building viable alternatives to conventional beef. Dissertation, University of California-Berkeley, California, USA.

Gwin, L. 2009. Scaling up sustainable livestock production: innovation and challenges for grass-fed beef in the U.S. Journal of Sustainable Agriculture 33(2):189-209. http://dx. doi.org/10.1080/10440040802660095

Gwin, L., and S. D. Hardesty. 2008. Northern California niche meat market demand study. University of California Cooperative Extension Small Farm Program, Davis, California, USA. [online] URL: http://cecentralsierra.ucanr. org/files/114197.pdf

Haggerty, J. H., and W. R. Travis. 2006. Out of administrative control: absentee owners, resident elk and the shifting nature of wildlife management in southwestern Montana. Geoforum 37:816-830. http://dx.doi.org/10.1016/j.geoforum.2005.12.004
Havstad, K. M., and D. P. C. Peters. 1999. People and rangeland biodiversity-North America. Proceedings of the VIth International Rangeland Congress, 2:634-638.

Havstad, K. M., D. P. C. Peters, R. Skaggs, J. Brown, B. Bestelmeyer, E. Fredrickson, J. Herrick, and J. Wright. 2007. Ecological services to and from rangelands of the United States. Ecological Economics 64:261-268. http://dx.doi. org/10.1016/j.ecolecon.2007.08.005

Hendrickson, M., and W. Heffernan. 2007. Concentration of agricultural markets. Department of Rural Sociology, University of Missouri, Columbia, Missouri, USA. [online] URL: http://www.foodcircles.missouri.edu/07contable.pdf

Heimlich, R. E., and W. D. Anderson. 1987. Dynamics of land use change in urbanizing areas: experience in the economic research service. Pages 135-154 in William Lockeretz, editor. Sustaining agriculture near cities. Soil and Water Conservation Service, Washington, D.C., USA.

Hinrichs, C. C., and R. Welsh. 2003. The effects of the industrialization of U.S. livestock agriculture on promoting sustainable production practices. Agriculture and Human Values 20:125-141. http://dx.doi.org/10.1023/A:1024061425531

Hodgson, J., and A. W. Ilius. 1996. The ecology and management of grazing systems. CAB International, Wallingford, UK.

Huntsinger, L., L. C. Forero, and A. Sulak. $2010 a$. Transhumance and pastoralist resilience in the western United States. Pastoralism: Research, Policy, and Practice 1(1):1-15. [online] URL: http://practicalaction.org/docs/publishing/ Transhumance and pastoralist resilience in the Western United States.pdf

Huntsinger, L., M. Johnson, M. Stafford, and J. Fried. $2010 b$. Hardwood rangeland landowners in California from 1985 to 2004: production, ecosystem services, and permanence. Rangeland Ecology \& Management 63(3):324-334. http://dx. doi.org/10.2111/08-166.1

Kelt, D. A., E. S. Konno, and J. A. Wilson. 2005. Habitat management for the endangered Stephens' kangaroo rat: the effect of mowing and grazing. Journal of Wildlife Management 69(1):424-429. http://dx.doi.org/10.2193/0022-541X (2005)069<0424:HMFTES > 2.0.CO;2

Kennedy, C. A., and M. W. Brunson. 2007. Creating a culture of innovation in ranching. Rangelands 29(3):35-40. http://dx. doi.org/10.2111/1551-501X(2007)29[35:CACOII]2.0.CO;2

Knapp, C. N., and M. E. Fernandez-Gimenez. 2009. Knowledge in practice: documenting rancher local knowledge in northwest Colorado. Rangeland Ecology \& Management 62(6):500-509. http://dx.doi.org/10.2111/08-175.1 
Knight, R. L., and C. White, editors. 2009. Conservation for a new generation: redefining natural resources management. Island Press, Washington, D.C., USA.

Kremen, C., A. Iles, and C. Bacon. 2012. Diversified farming systems: an agroecological, systems-based alternative to modern industrial agriculture. Ecology and Society 17(4): 44. http://dx.doi.org/10.5751/ES-05103-170444

Kremen, C., and A. Miles. 2012. Ecosystem services in biologically diversified versus conventional farming systems: benefits, externalities, and trade-offs Ecology and Society 17 (4): 40. http://dx.doi.org/10.5751/ES-05035-170440

Liffman, R. H., L. Huntsinger, and L. C. Forero. 2000. To ranch or not to ranch: home on the urban range? Journal of Range Management 53(4):362-370. http://dx.doi. org/10.2307/4003745

Lubowski, R. N., M. Vesterby, S. Bucholtz, A. Baez, and M. J. Roberts. 2006. Major uses of land in the United States, 2002. United States Department of Agriculture Economic Information Bulletin 14. [online] URL: http://americandreamcoalition. org/openspace/MajorLandUse.pdf

Maczko, K., J. A. Tanaka, R. Breckenridge, L. Hidinger, H. T. Heintz, W. E. Fox, U. P. Kreuter, C. S. Duke, J. E. Mitchell, and D. W. McCollum. 2011. Rangeland ecosystem goods and services: values and evaluation of opportunities for ranchers and land managers. Rangelands 33(5):30-36. http://dx.doi. org/10.2111/1551-501X-33.5.30

Maestas, J. D., R. L. Knight, and W. C. Gilgert. 2003. Biodiversity across a rural land-use gradient. Conservation Biology 17(5):1425-1434. http://dx.doi.org/10.1046/ j.1523-1739.2003.02371.x

Marty, J. T. 2005. Effects of cattle grazing on diversity in ephemeral wetlands. Conservation Biology 19(5):1626-1632. http://dx.doi.org/10.1111/j.1523-1739.2005.00198.x

McGinty, E. L., B. Baldwin, and R. Banner. 2009. Case studies: ranches in Utah exemplifying sustainable livestock production and range management. State of Utah Governor's Public Lands Policy Coordination Office, Salt Lake City, Utah, USA. [online] URL: http://extension.usu.edu/ utahrangelands/files/uploads/Case_Studies.pdf

Merenlender, A. M., L. Huntsinger, G. Guthey, and S. K. Fairfax. 2004. Land trusts and conservation easements: who is conserving what for whom? Conservation Biology 18 (1):65-76. http://dx.doi.org/10.1111/j.1523-1739.2004.00401. $\underline{\mathrm{x}}$

Moran, W., G. Blunden, and A. Bradly. 1996. Empowering family farms through cooperatives and producer marketing boards. Economic Geography 72(2):161-177. http://dx.doi. org/10.2307/144264
National Cattleman's Beef Association. 2012. Natural/ organic share of total beef (dollar). The Beef Checkoff Retail Marketing, Centennial, Colorado, USA. [online] URL: http:// www.beefretail.org/natural-organicshareoftotalbeefdollarandpound. $\underline{\operatorname{aspx}}$

Naylor, R., H. Steinfeld, W. Falcon, J. Galloway, V. Smil, E. Bradford, J. Alder, and H. Mooney. 2005. Losing the links between livestock and land. Science 310:1621-1622. http://dx. doi.org/10.1126/science.1117856

Niche Meat Processor Assistance Network. 2012. Overview of Mobile Units. NMPAN, Corvallis, Oregon, USA. [online] URL: http://www.nichemeatprocessing.org/mobile-unit-overview

Nickerson, C., R. Ebel, A. Borchers, and F. Carriazo. 2011. Major uses of land in the United States, 2007. U.S. Department of Agriculture Economic Research Service, Washington, D. C., USA. [online] URL: http://www.ers.usda.gov/Publications/ EIB89/EIB89.pdf

Oltjen, J. W., and J. L. Beckett. 1996. Role of ruminant livestock in sustainable agricultural systems. Journal of Animal Science 74:1406-1409.

Provenza, F. D. 2003. Foraging behavior: managing to survive in a world of change. Utah Agricultural Experiment Station, Logan, Utah, USA.

Provenza, F. D. 2007. Social organization, culture, and use of landscapes by livestock. Options Méditerranéennes 74:307-315.

Pyke, C. R., and J. Marty. 2005. Cattle grazing mediates climate change impacts on ephemeral wetlands. Conservation Biology 19(5):1619-1625. http://dx.doi.org/10.1111/ j.1523-1739.2005.00233.x

Resnik, J., G. Wallace, M. Brunson, and J. Mitchell. 2006. Open spaces, working places. Rangelands 28(5):4-9. http:// dx.doi.org/10.2111/1551-501X(2006)28[4:OSWP]2.0.CO;2

Richmond, O. M. W., S. K. Chen, B. B. Risk, J. Tecklin, and S. R. Beissinger. 2010. California black rails depend on irrigation-fed wetlands in the Sierra Nevada foothills. California Agriculture 64(2):85-93. http://dx.doi.org/10.3733/ ca.v064n02p85

Rinschede, G. 1984. Die wanderviehwirtschaft im gebirgigen westen der U.S.A. und ihre auswirkungen im naturraum [Transhumance in the western United States and its effects on natural areas]. Perfect Paperback F. Pustet, Regensburg, Germany.

Rissman, A. R., L. Lozier, T. Comendant, P. Kareiva, J. M. Kiesecker, M. R. Shaw, and A. M. Merenlender. 2007. Conservation easements: biodiversity protection and private use. Conservation Biology 21(3):709-718. http://dx.doi. org/10.1111/j.1523-1739.2007.00660.x 
Rissman, A. R., and N. F. Sayre. 2012. Conservation outcomes and social relations: a comparative study of private ranchland conservation easements. Society \& Natural Resources 25:523-538. http://dx.doi.org/10.1080/08941920.2011.580419

Rowe, H. I., E. T. Bartlett, and L. E. Swanson, Jr. 2001. Ranching motivations in 2 Colorado counties. Journal of Range Management 54(4):314-321. http://dx.doi. org/10.2307/4003098

Sayre, N. F. 2001. The new ranch handbook: a guide to restoring western rangelands. Quivira Coalition, Santa Fe, New Mexico, USA.

Sayre, N. F. 2002. Ranching, endangered species, and urbanization in the Southwest: species of capital. University of Arizona Press, Tucson, Arizona, USA.

Sayre, N. F. 2005. Working wilderness: the Malpai Borderlands Group story and the future of the western range. Rio Nuevo, Tucson, Arizona, USA..

Sayre, N. F., and M. Fernandez-Gimenez. 2003. The genesis of range science, with implications for pastoral development policy. Pages 1976-1985 in N. Allsopp, A. R. Palmer, S. J. Milton, K. P. Kirkman, G. I. H. Kerley, C. R. Hurt, and C. J. Brown, editors. Proceedings of the VIIth International Rangeland Congress. 26 July-1 August 2003, Durban, South Africa.

Smith, A. H., and W. E. Martin. 1972. Socioeconomic behavior of cattle ranchers, with implications for rural community development in the west. American Journal of Agricultural Economics 54(2):217-225. http://dx.doi. org/10.2307/1238704

Souder, J. A., and S. K. Fairfax. 1996. State trust lands: history, management, and sustainable use. University Press of Kansas, Lawrence, Kansas, USA.

Sulak, A., and L. Huntsinger. 2007. Public lands grazing in California: untapped conservation potential for private lands? Rangelands 29(3):9-12. http://dx.doi.org/10.2111/1551-501X (2007)29[9:PLGICU]2.0.CO;2

Theobald, D. M., H. Gosnell, and W. E. Riebsame. 1996. Land use and landscape change in the Colorado mountains II: a case study of the East River Valley. Mountain Research and Development 16(4):407-418. http://dx.doi.org/10.2307/3673990

Tilman, D., K. G. Cassman, P. A. Matson, R. Naylor, S. Polasky. 2002. Agricultural sustainability and intensive production practices. Nature 418:671-677. http://dx.doi. org/10.1038/nature01014

Toombs, T., J. H. Goldstein, C. Hanson, N. Robinson-Maness, and T. Fankhauser. 2011. Rangeland ecosystem services, risk management, and the ranch bottom line. Rangelands 33 (5):13-19. http://dx.doi.org/10.2111/1551-501X-33.5.13
Torell, L. A., and S. A. Bailey. 2000. Is the profit motive an important determinant of grazing land use and rancher motives? Journal of Agricultural and Resource Economics 25 (2):725-725.

Torell, L. A., S. Murugan, and O. A. Ramierz. 2010. Economics of flexible versus conservative stocking strategies to manage climate variability risk. Rangeland Ecology \& Management 63:415-425. http://dx.doi.org/10.2111/REMD-09-00131.1

Torell, L. A., N. R. Rimbey, O. A. Ramirez, and D. W. McCollum. 2005. Income earning potential versus consumptive amenities in determining ranchland values. Journal of Agricultural and Resource Economics 30 (3):537-560.

United States Department of Agriculture (USDA). 2009a. Facts on direct-to-consumer food marketing: incorporating data from the 2007 Census of Agriculture. U.S. Department of Agriculture Agricultural Marketing Service, Washington, D.C., USA. [online] URL: http://www.ams.usda.gov/ AMSv1.0/getfile?dDocName=STELPRDC5076729\&acct $=$ wdmgeninfo

United States Department of Agriculture (USDA). $2009 b$. Table 44. Selected practices: 2007. Pages 605-606 In 2007 Census of Agriculture - State Data. U.S. Department of Agriculture National Agricultural Statistics Service, Washington, D.C., USA. [online] URL: http://www.agcensus. usda.gov/Publications/2007/Full Report/Volume 1. Chapter 2 US State Level/st99 2044 044.pdf

United States Department of Agriculture (USDA). 2011. Farmers market growth 1994-2011. U.S. Department of Agriculture Agricultural Marketing Service, Washington, D. C., USA. [online] URL: http://www.ams.usda.gov/AMSv1.0/ ams.fetchTemplateData.do?template $=$ Template $S \&$ navID $=$ WholesaleandFarmersMarkets\&leftNav=WholesaleandFarmersMarkets\&page $=$ WFMFarmersMarketGrowth\&description $=$ Farmers\%20Market\%20Growth\&acct=frmrdirmkt

United States Department of Agriculture Economic Research Service (USDA-ERS). 2010. Organic production data sets. U.S. Department of Agriculture Economic Research Service, Washington, D.C., USA. [online] URL: http://www.ers.usda. gov/Data/Organic/

United States Department of Agriculture Natural Resources Conservation Service (USDA-NRCS). 2007. Summary report: 2007 natural resources inventory. U.S. Department of Agriculture Natural Resources Conservation Service, Washington, D.C., USA. [online] URL: http://www.nrcs. usda.gov/Internet/FSE DOCUMENTS//stelprdb1041379.pdf accessed Feb. 14, 2012. http://dx.doi.org/10.2172/910936

United States Department of Agriculture Natural Resources Conservation Service (USDA-NRCS). 2012. Financial 
assistance. U.S. Department of Agriculture Natural Resources Conservation Service, Washington, D.C., USA. [online] URL: http://www.nrcs.usda.gov/wps/portal/nrcs/main/national/programs/ financial

United States Department of Interior Fish and Wildlife Service (USDI-FWS). 2002. Endangered and threatened wildlife and plants; listing of the chiricahua leopard frog (Rana chiricahuensis). Final Rule. Federal Register 67(114): 40790-40811. U.S. Department of Interior, Washington, D. C., USA. [online] URL: http://www.fws.gov/southwest/es/ arizona/Documents/SpeciesDocs/CLF/CLF Final Rule.pdf

United States Forest Service (USFS). 2012. About rangelands. U.S. Forest Service, Washington, D.C., USA. [online] URL: http://www.fs.fed.us/rangelands/whoweare/index.shtml

Weiss, S. B. 1999. Cars, cows, and checkerspot butterflies: nitrogen deposition and management of nutrient-poor grasslands for a threatened species. Conservation Biology 13 (6):1476-1486. http://dx.doi.org/10.1046/j.1523-1739.1999.98468. $\underline{\mathrm{X}}$

White, C. 2008. Revolution on the range: the rise of the new ranch in the American West. Island Press, Washington, D.C., USA.

White, C. 2010. The carbon ranch. Quivira Coalition Report 36:3-18.

White, C., and C. Conley. 2007. Grassbank 2.0. Rangelands 29(3):27-30. http://dx.doi.org/10.2111/1551-501X(2007)29 [27:G]2.0.CO;2

White, R. J. 2000. Big game ranching. Pages 260-276 in S. Demarais and P. R. Krausman, editors. Ecology and management of large mammals in North America. Prentice Hall, Upper Saddle River, New Jersey, USA.

York, A. M., and M. L. Schoon. 2011. Collective action on the western range: coping with external and internal threats. International Journal of the Commons [online] URL: http:// www.thecommonsjournal.org/index.php/ijc/article/view/URN\% 3ANBN\%3ANL\%3AUI\%3A10-1-101640.

Yorks, T. P. 1989. Ranching native and exotic ungulates in the United States. Pages 268-285 in R. J. Hudson, K. R. Drew, and L. M. Baskin, editors. Wildlife production systems: economic utilization of wild ungulates. Cambridge University Press, Cambridge, UK.

Yung, L., and J. M. Belsky. 2007. Private property rights and community goods: negotiating landowner cooperation amid changing ownership on the Rocky Mountain Front. Society \& Natural Resources 20:689-703. http://dx.doi.org/10.1080/08$\underline{941920701216586}$ 